\title{
Queering the City: The Urban Chronicles of Pedro Lemebel
}

\author{
Neha Tyagi \\ Ph.D, Department of Germanic E Romance Studies, University of Delhi, \\ Email: neyha.tyagi@gmail.com, ORCID ID: oooo-ooo2-8518-4210
}

First published September 30, 2019

\begin{abstract}
In most of the societies around the world the underrepresentation of transgender and queer people in the spatial structures creates a setting for their subordination and exploitation. Moreover, this social discrimination is reflected in the queer spatial experiences, which are mostly restricted and prohibited, especially in the public spaces/sphere. Recognizing the marginalization and repression of the nonheteronormative queer identities, the paper would like to read on the works of Pedro Lemebel (1952-2015), one of the most prolific writer within the context of the Chilean dictatorship (1973-1990) and postdictatorship period and understand how his chronicles departs from the oppressed social space of/for queer people to stress on the subversive political strategies and spatial practices or what I call it here as 'queering', through which city space(s) could be re-signified by these non-heteronormative sexual and gender identities as a site for their vindication and visibilization.
\end{abstract}

Keywords: Pedro Lemebel, loca, queering, city, heteronormativity

\section{Introduction}

On the night of April 22 of the year 1973 in Chile, some thirty to fifty transgender took out a peacefully march on the street of the Plaza de Armas in Santiago de Chile to protest against police brutalities. But as one can imagine it was trampled by the police forces, who threatened the participating individuals with arrest. But the corollary of this protest unfolding during the presidency of the popularly elected Salvador Allende of the Unidad Popular (Popular Unity Party ) recognized as the political party which represented the poor of Chile was captured in press across the nation, where newspapers like El Clarin, one of the most popular pro-Allende daily portrayed queers as delinquents and ran headlines like "Faggots take over downtown Santiago"(Robles, 1998, p. 36) It's not complex to comprehend the media's response to the march which exhibited the hostility deep rooted in the society at the period towards the cause of the queer people, revealing the deeply rooted homophobia. Yet, the march crushed and suppressed marks a defiant moment in the history of the struggle of queer people in Chile. Besides in the context of Chile's political life, it was the same year the military coup on September 11 overthrew the democratically elected government, laying foundation of a dictatorship under General Augusto Pinochet (19731990), which had a lasting effect on the community, forcing them to return to their ghettos and wait for better times. Though curiously one notes that in the 1980 os the city of Santiago de Chile saw the emergence of swanky gay clubs which were as many believed a result of not the official

(C) AesthetixMS 2019. This Open Access article is published under a Creative Commons Attribution Non-Commercial 4.0 International License (http://creativecommons.org/licenses/by-nc/4.o/), which permits non-commercial re-use, distribution, and reproduction in any medium, provided the original work is properly cited. For citation use the DOI. For commercial re-use, please contact editor@rupkatha.com. 
tolerance (as homosexuality was only legalized in Chile in the year 1999) or relaxation of rules towards homosexuality and queer people, but rather a product of the neoliberal model embraced by the authority which recognized rich queer people as a potential market to be exploited for profit.

Taking note of these peculiar circumstances, we see chronicler Pedro Lemebel 'coming out' on the Chilean popular and literary scene. Considered as a defiant voice of the stigmatized loca, a transvestite homosexual who live out their effeminate natures by adopting females names, dressing in female clothing, and modifying body, and being one, Lemebel started off as an artist using performances as a way of intruding into the public debate and in the year 1987 formed an art collective called Las Yeguas del Apocalipsis (The mare of the Apocalypse) along with his friend and poet Francisco Casas which set out to conquer and reclaim the streets of Santiago. All through its active years i.e. between the late 1980 os and early 1990s, the duo sent shock waves throughout the city performing several art actions, which included appearing in drag, dressed in high heels and make-up, and riding naked on a horse across the city centre disrupting book launch nights, seminars and political events. And through these overtly sexualized and spatial performances, the duo questioned the abuse of the people by the dictatorial regime and exposed the hypocrisy of the Chilean society which has ignored the existence of various local queer communities. In a way, the performances of the Yeguas helped generate a movement that was meant to politicize several aspects that had yet not been represented in the national agenda, i.e., the rights of queer people and the AIDS. The Yeguas use of their "deviant" queer bodies as a public weapon of intervention, subversion, and defiance transformed them into an active agents of transgression within these urban spaces. The group's cross-dressed performances were also significant in their work to draw attention to the duplicities of the Chilean state and to warn of the control it exercised over the identities of its citizens. It is significant to understand here, that the duo used the very spaces where the state and its powers, as well as the oppressive aspects of the dominant culture exercised their control and departing from these oppressive social space assigned to/for the queer, they emphasized the subversive political strategies and spatial practices through which these space could be re-signified and/or redefined by non-heteronormative sexual and gender identities. In a way, the Yeguas intruding into the public spaces and participating in debates through their aggressively queer bodies as political and public symbols battled their invisibility in the midst of a repressive dictatorship and social order.

\section{Queering the City}

The city is not a mere geographical/ physical entity, a site of large human settlement but as an integral space of human experience where the social interactions between its diverse inhabitants are animated and discouraged, sanctioned and not approved, celebrated or punished and are regulated by the policies of the State and its dominant social structures. Even today in most of the cities holding the societies around the world, the fundamental division between public and private spaces is based on the binary division of gender, where open spaces are generally represented as masculine territories, while closed spaces are properly feminine, though with the closed spaces too the hierarchical binary norms are at play. There is thus an underrepresentation of the queer within these spatial structures. Furthermore, as far as the complexities of the dynamic relations between spaces and human societal structures are concerned, we see as social scientist and geographer Doreen Massey in her seminal work Space, Place and Gender (1994) argues, a space/place is always gendered, i.e. the so-called public places such as streets, shops, cafes, which seem "asexual" (automatically) assume heterosexual nature and which results in 
reproducing a heteronormative hegemony. The display of so-called heteronormative behavior which seems acceptable or rather appropriate also results in the underrepresentation reflected in/on the queer experiences vis-vis these public space/ sphere and creates a possible setting for their subordination and exploitation. Moreover, many times it is also expected that the people adhere to an unspoken ideal/norm of the heteronormative society by not "flaunting" their sexuality/genders in public spaces; meaning thereby that non-heteronormative identities should be 'non-threatening and almost invisible' or else they might face repercussions in the form of verbal or physical abuse. Likewise, as geographer Gill Valentine notes in her article 'Hetero)sexing space: lesbian perceptions and experiences of everyday spaces. Environment and Planning D: Society and Space (1993), the heteronormative regime is exposed in public spaces more completely, that is, heteronormativity as a dominant regime classifies human beings in two genders and defines the interaction between them in a natural way, such as sexuality, as a cultural dichotomy is located in private territory and:

is based on the false premise that heterosexuality is also defined by private sexual acts and is not expressed in the public arena...However, such is the strength of the assumption of the 'naturalness' of heterosexual hegemony, that most people are oblivious to the way it operates as a process of power relations in all spaces. (Valentine 1993, p.396, emphasis original)

The heteronormativity of public space which produces a marked division between public space (as Masculine) / private (as feminine) reinforce the invisibility, marginalization and spatial oppression of queer people and/or of people who show so-called "inappropriate" behaviour (according to patriarchal and heteronormative norms) in the public spaces is what geographer Lawrence Knoop also highlights in Gentrification and gay neighborhood formation in New Orleans. Homo Economics: Capitalism, community, and lesbian and gay life (1997).as the "gendered" public spaces become a site of contention because they involve exclusion and/or marginalization of nonconforming sexual identities and of people who display the so-called "inappropriate" behavior in otherwise public spaces.

Engaging with the investigations in this area and the various studies by feminist geographers like Elizabeth Grosz (1995), Doreen Massey (1994, 1999), Liz Bondi (1993) and Gill Valentine $(1989,1996)$ we can decipher conceptions about how space is influenced by gender throughout historical and political periods and how the production of urban space regulate the way in which people manifest themselves in these public spaces. Through these extensive works we come to understand that the hetero-patriarchal regime not only restricts the movement of subjects and manipulates the geographical spaces to their advantage but also regulate the behaviour or access to public spaces based on the gender and sexuality. Therefore, this division between 'the public' and 'the private' sphere becomes more complex when we focus on nonheteronormative sexualities and genders. For the same reason, in the recent queer politics we can find an acute critique of forced and prevalent heterosexual and heteronormative geography and the debate around the spatial policies which advocates the exclusion of certain sexualities and genders from public spaces, restricting them to a particular space, like the dominant spatial organization whose objective is to relegate women to the domestic sphere and queer people to the closet. In this context, it is imperative to also understand and recognize that social systems like class, ethnicity, age, and ability all work together, intersecting and producing complex oppressive regimes and determining the experience of women and queer people in the public spaces. 
Although parallel to these debates about the convoluted relationship between city/space and genders/sexualities, there is another dominant perception that has historically qualified cities as a refuge for depraved, delinquents, and queer people because cities offer space to meet in the audience. (Burgess, Park and McKenzie 1925; Wirth 1938)Then again, as the writer Michael Bronski (1998) sums up, being visible does not mean "being public" or being an integral part of public life in the state. Besides, it's not reasonable to ignore the fact that urban cities, especially the public spaces within the cities are not accessible but also dangerous for queer people.

It is for the very same reason that we see that the struggle for gender and sexual rights unfolding and emphasizing on taking over the public spaces. As feminist geographer Nancy Duncan elicits in Renegotiating gender and sexuality in public and private spaces; "The public sphere is not just the site of state politics and regulation, nor is it limited to the marketplace or the economy; it is also the site of oppositional social movements."(Duncan \& Duncan, 1996, p. 130)

As also the , historian George Chauncy (1996) notes that although the public spaces still remain dangerous for queer individuals in majority of societies across the globe, the struggle for the control of these space has become fundamental for queer culture and politics throughout the twentieth century, and at present we see that the long battle of the sexual/gender minorities to achieve rights and reclaim public spaces explicitly includes spatial strategies such as 'coming out of the closet to the street', marches of pride, and demonstrations.

Consequently, as we see in the context of Chile the Yeguas through their art actions and spatial tactics like marches, public protests, performances art, street theater and demonstrating overtly sexual behavior such as kissing in public of 'queers' the spaces, which while primarily recognizing the heteronormative nature of most urban spaces, destabilizes the discriminatory and oppressive norms of the society dominating these spaces. The Yeguas as an principal collective which presented a strong critique of the repressive Chilean society, the authoritarian government, its policies and oppression intersecting hegemonic categories of the sexuality, gender, class, ethnicity, race, etc. remained active in the cultural scene till the year 1995.

It is during the same year Lemebel published his first collection of chronicles titled $L a$ Esquina es mi Corazon (The corner is my heart), which was followed by namely, Loco Afán(1996), De Perlas y cicatrices(1998), Adios Marquita Linda(2004), Serenta Cafiola(2008) among others, in which he continued focusing on queer subjects and their lives producing the possibilities of alternative sensibility in the city of Santiago a contemporary dynamic space that does not exist only in physical geography but has been the subject of literary and essayistic treatment that attempts to describe and understand it through language, evocations and images written in words. And within the myriad ways of narrating the city, the urban chronicle emergences as the genre in which the city is not only a field of action but is a protagonist itself. . In the urban chronicles as professor Julio Ramos (2001) notes, the chronicler organizes and integrates the fragments of modern experience through "the rhetoric of strolling" (Ramos, 2001). In a way the chronicles becomes both a literary narrative form and social commentary that tries not only to build the city through words and images but also carries a critique of the constant transformations that occur in this space.

With Lemebel we see that the genre of urban chronicles travels across various medium, appearing in newspapers and magazines and performed on radio stations before entering the book format, where the inclusion of photographs operates as pictorial chronicles and excerpts 
from popular song lyrics provide a distinctive oral aura enabling our chronicler to capture and represents this dynamic city space. This hybrid nature of his work also has an impact on final production in the sense that it forces the audience to use all their senses to grasp the situations the chronicler is attempting to portray, which in the given case are the multiples cities that exist in the city. At the same time we see that in Lemebel's chronicles 'the city', in general, is presented as a dangerous, impersonal and dehumanizing space, hiding the past political brutalities, and one that sustains unequal social and economic boundaries where people struggle to survive and keep up with the urban life.

Thus, in many of his chronicles in the collection La esquina es mi Corazon first published in 1995. Lemebel takes his readers to the marginal spaces inhabited by the poor prostitutes, the transvestites, the homeless, the sick, working class people and all those that conservative upper and middle classes of Santiago avoid. It would not be incorrect to say that in representing these subjects the chronicler not only attempts to disrupt the orderly urban division of the city space but also reveal how this systematic division by the authority into closed blocks and organized public spaces can be challenged by the conquest of these spaces by the queer desires of the marginalized individuals.

Besides, reflecting on the impact of the neoliberal policies enthusiastically adopted by the regime and which further greatly shaped the city spaces, the chronicler in his chronicle Nalgas Lycra, Sodoma Disco (Loco Afan, 1998) acknowledges the emergence of so-called closed gay spaces like clandestine clubs in Chile, which in the 8os became the institutionalized site/ scene of the gay cause, reproducing what he calls the "only for men Travolta model" (Lemebel 2000). These exclusive closed gay spaces like the clubs and discos or as Lemebel calls them 'homo temples' becomes centers, "where dance reunites the Ghetto with more success than the political militancy"(Lemebel 2000, p.53; my translation), imposing a lifestyle and a philosophy of virile camouflage which through fashion homogenizes the diverse local non-heternormative sexualities existing in the Chilean society. Perhaps, that why for the chronicler these are not the spaces from which emergence the resistance and...but instead the public spaces like the public parks, football stadiums, beaches and the public buses, are the actual sites of transgression.

As we see in the chronicle, Anacondas en el parque (La esquina es mi corazón: crónica urbana, 1995) the chronicler represents the public park in central Santiago, a place for recreation which has come to represent a space regulated by different social norms with a set of rules and codes regulating for the general/heterosexual use. Lemebel projects this image of a public space as a site of a political controlling in the modern societies immobilized by the authority behind the (CCTV) cameras installed here to keep a check on its citizens. The chronicler critical representation of the public park where the surveillance put in place by the state authority controls and regulates activities of the people frequenting this space, demonstrates the extent to which the authority goes to keep under control its citizens. Public parks which are mostly used by families with children to spend a day of recreation and rest is also the place where space-time pair works in tandem, there are certain timing and a set of rules for the use of the park. Therefore, in order to defy the rules of the game as established by the power that is, Lemebel produces a scene after the sunset, where the park, a space with all the due surveillance apparatus becomes a space of transgression that happens with the occupation of it by the not permitted ones. Though there are also the young 'hetero' couples coming to park because they can't afford to rent a room in a motel and are hesitant in their expression of desires, the behavior of queer people who frequent 
this place, do not follow the set standards of decency and even under the watchful eye of the state manages to transgress the order imposed within this public space and by having sex in public space these individuals give new social meanings to this space. The park in the night becomes a place where queer desires through "Collective masturbations recycle childhood games in desperate maneuvers; the slide, the swing, the rocking chair, the twilight hiding place for brotherhoods of grown men, who bond, rudder erect, in the summation of their cartilage." (Lemebel 2004, p.8, my translation) are formed and expressed, and where "Workers, clerks, students, or seminarians, they are transformed into ophidians who shed the dry skin of their uniforms to tribalize desire in an opaque rattling event" (Lemebel 2004, p.8, my translation) and transforms this morbid space into a place of action. These spontaneous sexual desires disrupts the smooth function of a park, ceases to be a so-called civilized space of recreation and becomes a jungle of erotic desires where diverse sexual alliances are formed. Besides, we can see these actions/acts as not only transgressive, in that they trespass on territory that is taken for granted as heterosexual but also transformative in that they publicly articulate sexualities that are assumed to be 'private' and change the way we understand the city's urban spaces by exposing its performative nature by challenging the heterosexual hegemony of the space.

\section{Conclusion}

As Gill Valentine notes in (Re) Negotiating the 'heterosexual street' Lesbian productions of Space (1996) the aggressive tactics employed by the lesbians not only raises their visibility but also shatter the taken -for -granted heterosexuality of street and reproduce them as queer sites. The protagonists of these chronicles marginalized due to their appearances, their passionate desires and their social status, like the chronicler himself are not only poorly represented in the public sphere but also constantly suffer both physical and symbolic violence. Understanding the social discrimination and limitation for the sexual minority which is reflected in their spatial experiences, Lemebel underlines the importance of capturing the spaces that are supposedly not "permitted to be occupied" by the excluded, the marginalized, and the queer people. Consequently, in his writings, the spatialization of sexuality reflects the performativity of sexual identities that constantly questions the hegemony of the heterosexual norms and therefore the parks in the neoliberal city, like the old cinemas, the public toilets of the football stadium, the old Turkish bath, and public buses, all become the place of cruising, where the people marginalized by their body and homoerotic passion using a language and secret codes constantly resist the hegemonic norms. In this manner, in the chronicles the active queering of the spaces through eruptions of desire, the removal of the boundary between the public and the private and various spatial practices which loosen the order not only exposes the unfairness of the existing social order but also aggressively imposes a queer vision upon public spaces and which help fight against the ghettoization of queer people in the city.

\section{References}

Bondi, L. (1993). Locating Identity Politics. In S. Pile \& M. Keith (Eds.), Place and the Politics of Identity (pp. 84-101). London: Routlegde.

Bronski, M. (2000). The pleasure principle: Sex, backlash, and the struggle for gay freedom. New York: St. Martins Press. 
Chauncey, G. (1997). Gay New York: Gender, urban culture, and the making of the gay male world. New York: BasicBooks.

Duncan, N. (1996). Renegotiating gender and sexuality in public and private spaces. In N. Duncan (Ed.), Bodyspace: Destabilizing Geographies of Gender and Sexuality (pp. 127-145). London: Routlegde.

Foucault, M. (1995). Discipline and Punish: The birth of the prison. New York: Vintage Books.

Grosz, E. A. (1995). Space, time, and perversion: Essays on the politics of bodies. New York: Routledge.

Knopp, L. (1997). Gentrification and gay neighborhood formation in New Orleans: A case study. In A. Gluckman \& B. Reed (Authors), Homo economics: Capitalism, community, and lesbian and gay life (pp. 45-63). London: Routlegde.

Lemebel, P. (200o). Loco afán: Crónicas de sidario (Contraseñas). Barcelona: Anagrama. Retrieved June 3, 2017, from https://www.scribd.com/document/1 2003995 1/Loco-Afan-de-Pedro-Lemebel.

Lemebel, P. (2004). La esquina es mi corazón: Crónica urbana. Santiago de Chile: Seix Barral. doi:https://www.scribd.com/doc/56827850/Pedro-Lemebel-La-Esquina-Es-Mi-Corazon.

Massey, D.B.(1994). Space, place, and gender. Minneapolis (Minessota, Estados Unidos): University of Minnesota Press.

Ramos, J. (2001). Divergent modernities: Culture and politics in nineteenth-century Latin America. Durham, NC: Duke University Press.

Robles, V. H. (1998). History in the Making The Homosexual Liberation Movement in Chile (4th ed., Vol. 31, NACLA Report on the Americas, pp. 36-44, Rep.). doi:https://doi.org/10.108o/10714839.1998.11725707

Valentine, G. (1996). (Re)negotiating the 'heterosexual street': Lesbian productions of space. In N. Duncan (Ed.), Bodyspace: Destabilizing Geographies of Gender and Sexuality (pp. 146-155). London: Routlegde.

Ph.D, Hispanic Studies, Department of Germanic \& Romance Studies, University of Delhi. My research focuses on the works of the contemporary Chilean writer Pedro Lemebel (1950-2015) within the contexts of the Chilean dictatorship and post-dictatorship neoliberal democracy. Research specialization includes contemporary Latin American literature and history; post dictatorial Chilean Literature, Gender and Queer Studies. 